\title{
Inversion and Abolition: On the Upside-Down Logics of Wealth, Poverty, and Capital
}

\author{
Richard Gilman-Opalsky ${ }^{1}$
}

[Article copies available for a fee from The Transformative Studies Institute. E-mail address: journal@transformativestudies.org Website: http://www.transformativestudies.org (c2018 by The Transformative Studies Institute. All rights reserved.]

\section{UPSIDE-DOWN}

The capitalist world is upside-down. A world governed by capital is a world organized and ruled by fatal logics: Everyday life from childhood to death (from childcare to the death and dying industries) is governed by the logics of profit and private property. Thus, our ability to secure the most basic things from food and shelter to education and healthcare is largely decided by our ability to pay, and concentrations of wealth determine the form and content of political power. As every child is well-taught and knows, money should not govern human life; and yet it does.

One upside-down perspective views capital as wealth, but capital is not wealth. Capital is a power, whereas wealth is a certain property (or a composite of aggregate properties). Poverty specifies a relative absence of properties, including those properties needed to secure the most basic things mentioned above. It is remarkable and absurd that capitalism has come to be associated with wealth. Global macroeconomic data shows that capitalism and its neoliberal growth have in fact grown income inequality and intensified the brutal exclusions of poverty. ${ }^{2}$ It is not only upside-down that we do not associate capitalism with inequality and poverty, but also that we do not associate it with the ruthless and rampant capitalism of India, Liberia, Haiti, Honduras, Indonesia, Colombia, and

\footnotetext{
${ }^{1}$ Richard Gilman-Opalsky, Ph.D., is Associate Professor of Political Philosophy at the University of Illinois in the Department of Political Science. Address correspondence to: Dr. Richard Gilman-Opalsky, University of Illinois, Public Affairs Center, Room \# 362, Springfield, IL 62703-5407; Tel.: 217.206.8328; e-mail: rgilm3@uis.edu; Page: http://www.uis.edu/politicalscience/faculty/gilman-opalsky/.

${ }^{2}$ Saskia Sassen, Expulsions: Brutality and Complexity in the Global Economy (Cambridge and London: Harvard University Press, 2014).
} 